\title{
Verbascum Thapsus (Mullein) Versatile Polarity Extracts: GC-MS Analysis, Phytochemical Profiling, Anti-bacterial Potential and Anti-oxidant Activity
}

\author{
Ali Nadeem1, Bashir Ahmed ${ }^{1, *}$, Hira Shahzad², Lyle E. Craker³, Tudor Muntean ${ }^{3}$
}

\section{Ali Nadeem ${ }^{1}$, Bashir Ahmed ${ }^{1, *}$, Hira Shahzad ${ }^{2}$, Lyle E. Craker ${ }^{3}$, Tudor Muntean ${ }^{3}$}

\section{'Department of Biological Sciences,} International Islamic University, Islamabad, PAKISTAN.

${ }^{2}$ Department of Biochemistry, PMAS Arid agriculture University, Rawalpindi, PAKISTAN. ${ }^{3}$ Department of Plant Biology, Stockbridge school of Agriculture, University of Massachusetts, Amherst, Massachusetts, USA.

\section{Correspondence}

Bashir Ahmed

Department of Biological Sciences, International Islamic University, Islamabad, PAKISTAN

E-mail: bashir.ahmad@iiu.edu.pk ; drbashir. iiui@gmail.com

History

- Submission Date: 01-08-2021;

- Review completed: 25-08-2021;

- Accepted Date: 01-09-2021.

DOI : 10.5530/pj.2021.13.189

Article Available online

http://www.phcogj.com/v13/i6

\section{Copyright}

(C) 2021 Phcogi.Com. This is an openaccess article distributed under the terms of the Creative Commons Attribution 4.0 International license.

\begin{abstract}
Verbascum thapsus is naturally grown in the Himalayas and widely used in herbal teas and traditional herbal medicine for its anticarcinogenic and anti-inflammatory properties. The present study was designed to majority of leaf extracts from Verbascum thapsus. All extracts were analysed for phytochemical properties, antioxidant capacity and antimicrobial potential against both Gram-positive and Gram-negative bacteria. Biochemical investigations and GC-MS analysis was used for identifying phytochemicals. DPPH assay, Kirby's Disc Diffusion method (KDM), 96 well test, and Resazurin test were performed for antioxidant and antimicrobial investigation. Results indicate that verbascum thapsus grown in Pakistan is rich in alkaloids and phenols. Noteworthy antibacterial activity was observed against S. sonnei, L. lactis, B. subtilis, C. freundii, K. oxytoca, L. monocytogenes, and S. enterica. GCMS analyses of $\mathrm{V}$. thapsus extracts revealed the presence of medically important bio compounds including Hexadecanoic acid, methyl es and Stigmasterol (antibacterial activity), 2(5H)-Furanone (appetite suppressant), 3-Hydroxy-.beta.-damascone (anti-inflammatory properties), Squalene (antiaging, anti-inflammatory, anti-acne, eczema), Vitamin E and 2-Methoxy-4-vinylphenol (antioxidants). Antioxidant radical scavenging activity was determined from acetone extract of $\mathrm{V}$. thapsus. This study concludes remarkable antibacterial and antioxidant potential in Verbascum Thapsus leaf extracts.

Key words: Verbascum Thapsus; GC/GC-MS; plant biotechnology, Microbiology.
\end{abstract}

\section{INTRODUCTION}

Cure of microbial ailments via plant extracts is in practice for centuries ${ }^{1}$ deals with infectious diseases because of their antibiotic and antioxidant potential. Verbascum thapsus also known as common mullein is utilized as traditional medicine and tea rich in antioxidants and antibacterial plants for long time $e^{1,2}$. More than one hundred accepted names are given to large genus Verbascum belonging from Scrophulariaceae family in plant databases $^{3}$. Leaves and flowers of V. Thapsus have expectorant and anti-inflammatory potential in herbal medicines ${ }^{4}$. V. thapsus reduces the severity of respiratory conditions including bronchitis and asthma along with reported effectiveness against haemorrhoids, fungal infections, and diarrhea ${ }^{5}$. Yet, the detailed phytochemical spectrum in versatile solvents remains relatively understudied. Plants from Verbascum genus have exhibited inhibitory activity against murine lymphocytic leukaemia, several strains of influenza viruses, Trichomonas vaginalis, etc. ${ }^{2}$. Plants of Verbascum species also have potential anticarcinogenic properties. Verbascum Thapsus has been used as herbal treatment of several disorders, but no FDA approved drug is yet available. Prominent medicinal uses include treatment for Parkinson's disease, diabetes, bronchitis, asthma, joints and stomach pain, and skin issues etc ${ }^{3}$. Flower extracts of $\mathrm{V}$. Thapsus also show promising concentrations of Terpenoids. Iridoid glycosides, Lignan glycosides, phenylethanoid glycosides, sterones and saponins etc $^{3,6}$. Verbascum thapsus is extensively grown in temperate areas of Pakistan ${ }^{5}$ and its medicinal importance prompted us to study it comprehensively. The phytochemistry of Verbascum thapsus is usually studied in a single solvent i.e., methanol, in the past decade $^{7}$ and not a single study discusses it in all five range of solvents. Therefore, in continuation of prior studies, the present study aims to explore multiple aspects i.e., phytochemical analyses of Verbascum thapsus and quantitative/qualitative investigations via GCMS and its antibacterial activities in five different solvents (Figure 1).

\section{RESULTS AND DISCUSSION}

Verbascum thapsus is used in the treatment of pulmonary problems, inflammatory diseases, asthma, spasmodic coughs, diarrhoea, tuberculosis, and migraine headaches, it also possesses antiviral, anti-cancer, and antibacterial potential ${ }^{8,10}$. Numerous bioactive agents have been extracted from oils and other extracts of Verbascum species ${ }^{11}$.

\section{Phytochemical analysis}

The phytochemical profiling of Verbascum thapsus extracts in methanol, ethanol, water, acetone, and hexane was performed to reveal phenol, alkaloids, tannins, saponins, cardiac glycosides, flavonoids, water-soluble phenols, water-insoluble phenols, triterpenoids, free anthraquinones, and combined anthraquinones (Table 1). Alkaloids and phenols were present in most extracts while saponins and combined anthraquinones were only detected in water-based solvents. The highest flavonoid content was present in acetone extract (3.1969 ug/ $\mathrm{ml})$ and the highest phenol content (2.770 ug/ $\mathrm{ml}$ ) was present in methanol extract (Figure 2). 

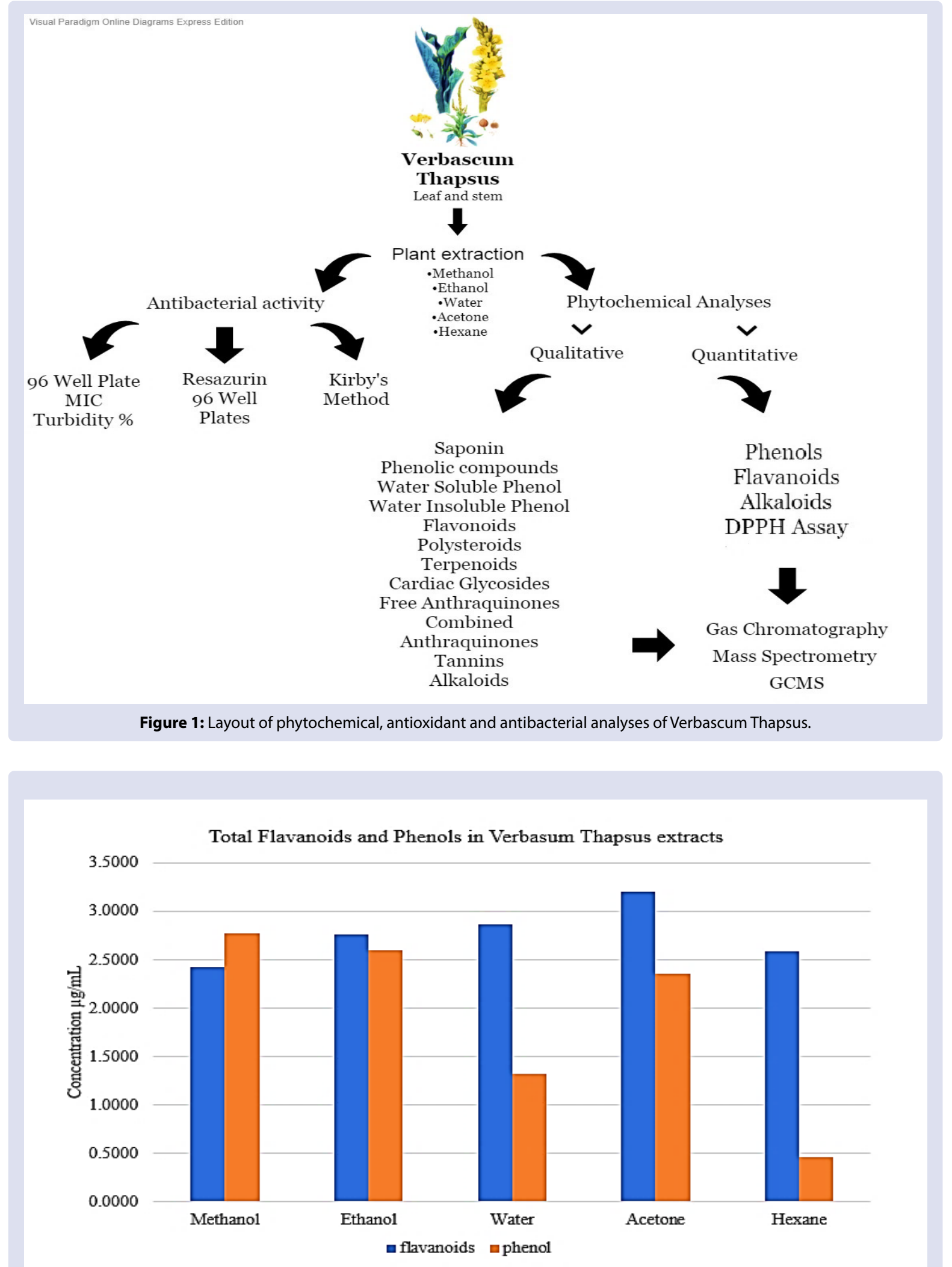

Figure 2: Total flavonoid and phenol estimation in Methanol, ethanol, water, acetone and hexane extracts of Verbascum Thapsus. $\mathrm{X}$ axis indicate the extracts in different solvents whereas concentration of flavonoid and phenol is represented in $\mathrm{ug} / \mathrm{ml}$ on $\mathrm{y}$ axis. 
Table 1: Qualitative presence or catalogue of phytochemicals of Verbascum thapsus in the plants extracts in different solvents.

\begin{tabular}{|c|c|c|c|c|c|}
\hline Phytochemical molecules & Water & Methanol & Ethanol & Acetone & Hexane \\
\hline Phenol & + & + & + & + & - \\
\hline Alkaloids & + & + & + & + & + \\
\hline Tannins & - & - & + & + & + \\
\hline Saponins & + & - & - & - & - \\
\hline Cardiac glycosides & - & - & + & + & + \\
\hline Flavonoids & - & + & + & + & - \\
\hline Water soluble phenols & + & + & - & - & - \\
\hline Water insoluble phenols & - & + & + & + & - \\
\hline Triterpenoids & + & - & - & - & - \\
\hline Free anthraquinones & + & - & + & - & - \\
\hline Combined anthraquinones & + & - & - & - & - \\
\hline
\end{tabular}

(+) indicate the presence of phytochemicals; (-) indicate the absence of the phytochemicals.

(a) GCMS Spectral Chromatogram of Methanol Extract of Verbascum Thapsus.

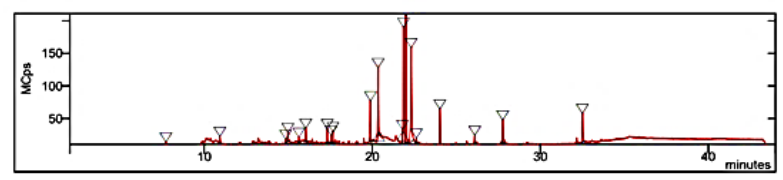

(c) GCMS Spectral Chromatogram of Water Extract of Verbascum Thapsus

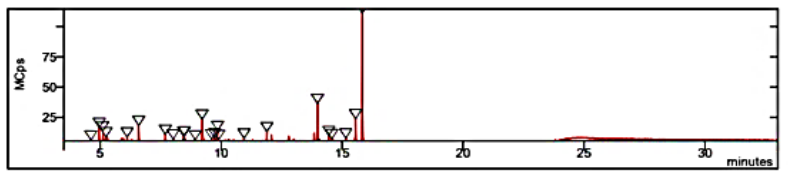

(b) GCMS Spectral Chromatogram of Ethanol Extract of Verbascum Thapsus.

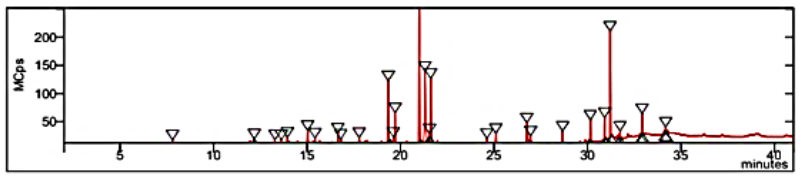

(d) GCMS Spectral Chromatogram of Acetone Extract of Verbascum Thapsus.

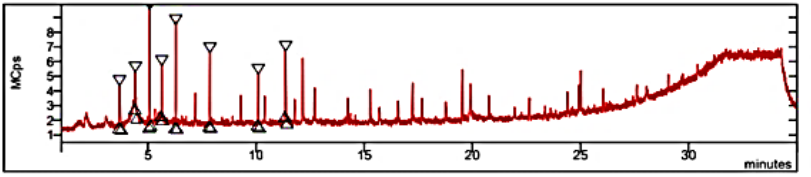

(e) GCMS Spectral Chromatogram of Hexane Extract of Verbascum Thapsus.

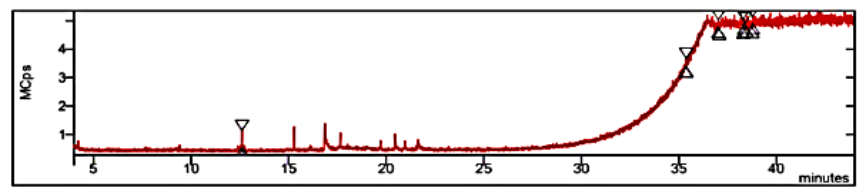

Figure 3: Gas Chromatography Mass Spectrometry GCMS analysis of Verbascum extracts in solvents (a) Methanol, (b) Ethanol, (c) Water, (d) Acetone, and (e) Hexane.

Phenolic and flavonoid compounds enhance the antioxidant activity of plants and are pharmaceutically important. Enormous antimicrobial, antioxidant, antitumorigenic, cardiovascular protective, immuneboosting, and anti-inflammatory effects ${ }^{12}$ are highlighted in earlier studies. Sufficient phenol and flavonoid percentage may contribute to prior mentioned pharmaceutical benefits ${ }^{13}$. Several Verbascum species like V. phlomoides, V. pestalozzae, V. detersile, V. densiflorum contain important phytochemicals in the phenol range that makes them pharmacologically important ${ }^{3,14,16}$.

\section{GCMS analysis}

Methanolic extract of Verbascum thapsus showed the presence of 25 phytochemicals, while 41 phytochemicals were detected in ethanolic extracts. In the water extract, 15 phytochemicals were detected while 29 phytochemicals were detected in acetone extracts (Figure 3 , Supplementary Table 2). Fifteen phytochemicals were detected in hexane extract. Mass spectrometric analysis of V. thapsus extracts revealed the presence of many important compounds. Ethanolic extract, alone, contains 41 bioactive compounds. However, the least number of metabolites were present in the water and hexanebased extract of V. thapsus. Some prominent compounds include 2-Methoxy-4-vinylphenol (antioxidant, flavouring agent, antiinflammatory effect), Phosphonic acid (medical imaging, pro-drug),
Stigmasterol and Hexa-decanoic acid, methyl es (antibacterial activity), n-Hexa-decanoic acid (cosmetics) and Vanillic acid (flavouring agent), 2(5H)-Furanone (appetite suppressant), 3-Hydroxy-.beta.-damascone (anti-inflammatory properties), Mequinol (skin depigmentation), Fluoroacetic acid, dodecyl ester (pesticide), Squalene (antiaging, antiinflammatory, acne, eczema), Vitamin E (antioxidant), Hydroquinone (hyperpigmentation) and Phytol (fragrance agent, transcription modulator). We would like to report many chemicals that did not match any reference molecule in GCMS library. These may have potential antioxidant, antimicrobial or any other activities. Therefore, it is of vital importance to identify and separate the unmatched compounds (Supplementary Table 2) via further analytical techniques like Mass spectrometry and flow cytometry. Further experiments could be conducted to evaluate the pharmacological potential of these unknown compounds present in Verbascum Thapsus extracts.

Plants use metabolites for their defence against pathogenic microbes using various strategies. These metabolites contribute to the intervention of microbe invasion and repel herbivores from potential harm they may pose to plant survival and activity ${ }^{17,18}$. Furthermore, new antibiotics are demanded worldwide to answer the question arise by antibiotic resistant variants ${ }^{3,19}$. Pure plants and herbal extracts are used universally to design chemicals of pharmaceutical importance. 


\section{Antibacterial activity}

Antibacterial experiments (well plate method, Kirby's disc diffusion method, and resazurin absorption method) were performed on ten bacterial strains. Gram-positive strains included: Bacillus subtilis (ATCC_6051), Micrococcus luteus (ATCC_4698), Staphylococcus aureus (ATCC_25923), Lactococcus lactis (ATCC_LMO230), Listeria monocytogenes (ATCC_LM21) while the gram-negative bacterial strains included: Shigella sonnei (ATCC_25931), Salmonella enterica (ATCC_14028), Escherichia coli (ATCC_25922) and Klebsiella oxytoca (ATCC_43863). Overall maximum antimicrobial activity was displayed by ethanol and methanol-based extracts of $\mathrm{V}$. Thapsus against most of the bacterial strains. Maximum percent growth inhibition of S. sonnei was produced by ethanol extract at $1000 \mathrm{ug}$ concentration. However, both ethanol and methanol extracts at 1000ug and 500ug concentration showed growth inhibition of L. lactis and C. freundii. Acetone based extract inhibited the growth of L. monocytogenes, L. lactis, and B. subtilis. On the other hand, water-based extracts of V. thapsus showed the least bacterial growth inhibition against all the bacterial strains.

Kirby disk diffusion method was used to study the bacterial growth inhibition by plant extract in various solvents. Ethanol, methanol, and acetone-based extracts showed significant antimicrobial activity against most of the bacterial strains while water and hexane-based extracts showed least antibacterial activity as compared to control treatment. Maximum inhibition was observed against C. freundii, M. luteus, S. sonnei, and K. oxytoca (Supplementary Table 3). The average diameter $(\mathrm{mm})$ of inhibition zone in culture plates was recorded in triplicate and the mean value \pm standard deviation of diameter has been presented in Supplementary files as table 3. Verbascum thapsus total extract showed amazing MIC in terms of percentage growth inhibition against L. lactis, E. coli, and K. oxytoca. (Figure 4). More than seventy percent of bacterial growth of $\mathrm{L}$ lactis was inhibited via $\mathrm{V}$. thapsus extract at 100ul concentration.

Well plate method and Kirby's disc diffusion method indicated maximum antimicrobial activity of ethanol, methanol, and acetone extracts of V. thapsus (Figure 5). Our results support previous findings ${ }^{18,20,21}$ where ethanolic and methanolic extracts performed better in antibacterial action as compared to aqueous extracts. One way ANOVA results indicate a significant difference ( $p$-value: $<0.05)$ in the antibacterial activity of Verbascum extracts (Figure 6).

Another experiment of DMSO mediated solubilization was conducted. Studies report prominent antimicrobial action of V. thapsus extracts against S. epidermidis, S. aureus, K. pneumonia, and E coli strains ${ }^{18}$. The present study explored the promising antibacterial activity of V. thapsus against L. lactis, E. coli, and K. oxytoca. Our results not only validate the research findings of the antibacterial properties of V. Thapsus ${ }^{22}$ but also coincide with the other Verbascum species i.e., Verbascum macrurum ${ }^{23}$. It is therefore indicated that significant antimicrobial potential in Verbascum species ranks them high as medicinal plants ${ }^{18,24}$.

\section{DPPH antioxidant activity}

The use of DPPH to evaluate antioxidant activity in plant extracts. The highest antioxidant activity was recorded in acetone extract of $\mathrm{V}$. thapsus $(651.03125 \mathrm{umol} / \mathrm{L})$ followed by water-based extracts (Figure 7 ). The antioxidant order of V. thapsus extract was acetone $>$ water $>$ hexane $>$ ethanol $>$ methanol. The lowest IC50 value shows the highest antioxidant potential of extracts. This indicates the presence of free radical scavenging active metabolites and makes this plant a good antioxidant ${ }^{25,26}$. On the contrary, prior studies indicated the maximum antioxidant potential of Verbascum plant species in water and methanol extracts $^{27,28}$. For long, Verbascum species have been used in several regions across the globe for their antitumorigenic, anti-inflammatory, and anti-spasmodic effects along with diminishing migraine symptoms and wound healing ${ }^{12,23}$. Several other investigations also highlighted the antioxidant activity of Verbascum species in hydrophilic solvents ${ }^{26,29}$. Therefore, the antioxidant activity of V. thapsus revealed from our study is supported by other studies. The presence of phenolic compounds and antioxidants may provide advantageous health and medicinal benefits by Verbascum consumption in either raw or processed form after intensive tests and trials ${ }^{25}$.

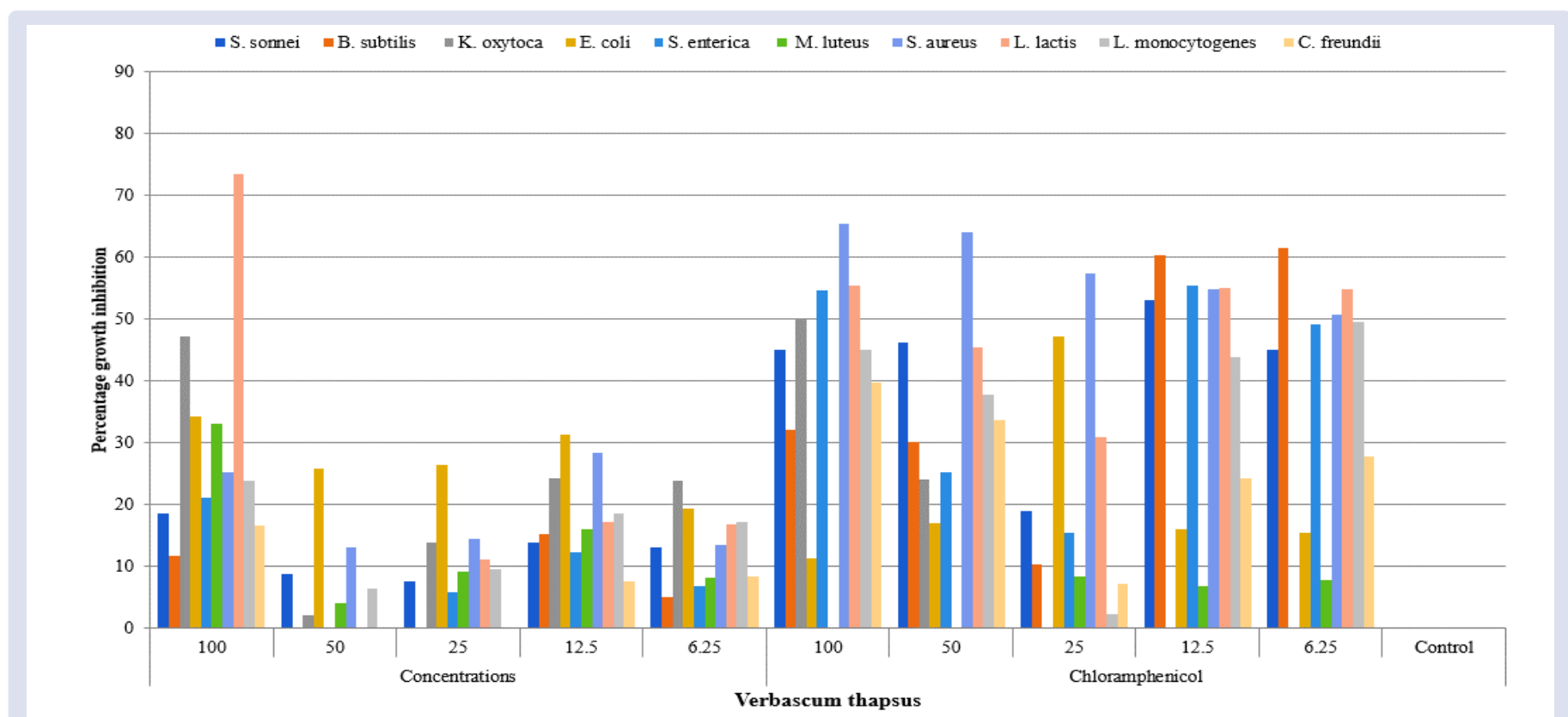

Figure 4: Resazurin method - Antimicrobial Efficacy of Verbascum thapsus Plant Extract Against Bacterial Isolates. DMSO mediated combined plant extract is shown in $\mathrm{x}$ axis in varying concentrations i.e., serial dilution in $\mathrm{ug} / \mathrm{ml}$ followed by chloramphenicol as control treatment. 


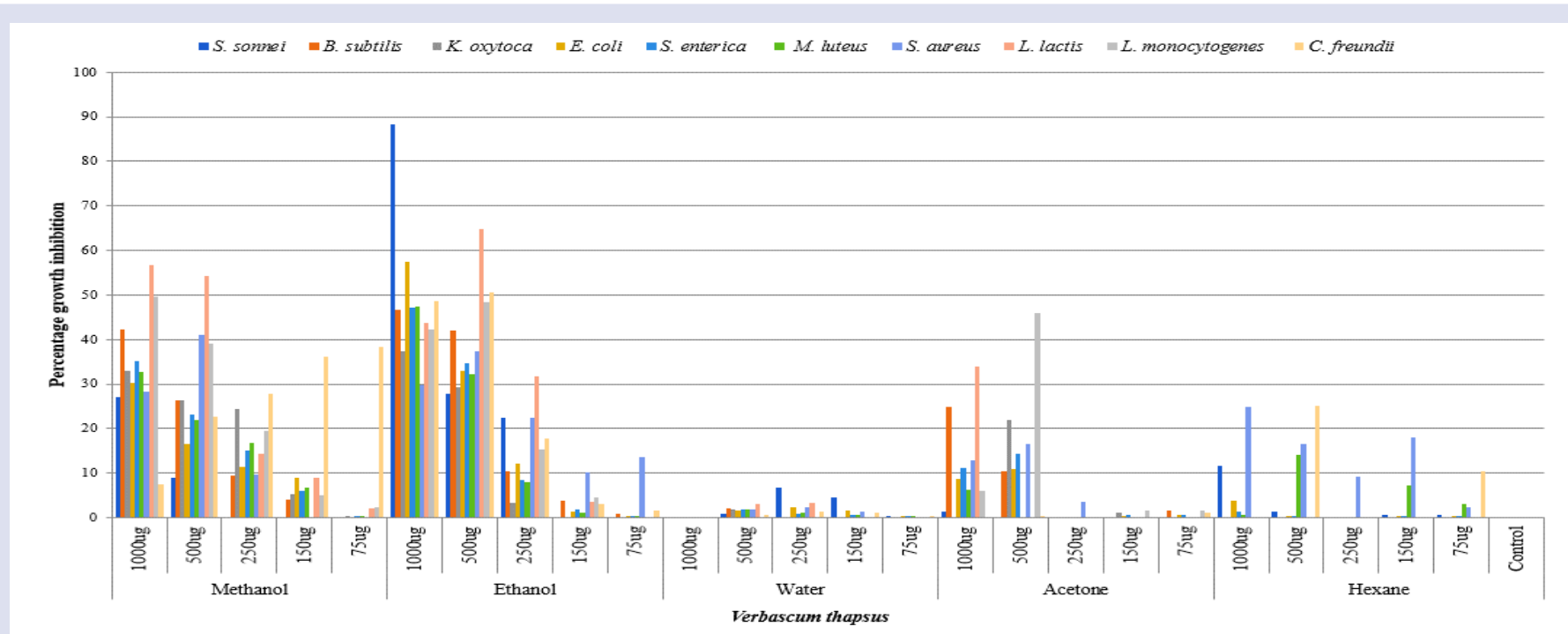

Figure 5: Determination of Minimum Inhibitory Concentrations (MIC) by Well plate method for Gram positive and negative bacterial strains in response to Verbascum Thapsus extracts in various solvents and concentrations (methanol, ethanol, water, acetone, and hexane). Y axis exhibit growth inhibition in percentage form i.e., region of growth inhibition / control growth $\mathrm{X} 100 . \mathrm{X}$ axis indicate leaf extracts in different concentrations i.e. $1000 \mathrm{ug} / \mathrm{ml}, 500 \mathrm{ug} / \mathrm{ml}$, $250 \mathrm{ug} / \mathrm{ml}, 150 \mathrm{ug} / \mathrm{ml}$ and $75 \mathrm{ug} / \mathrm{ml}$ of pure solvent.

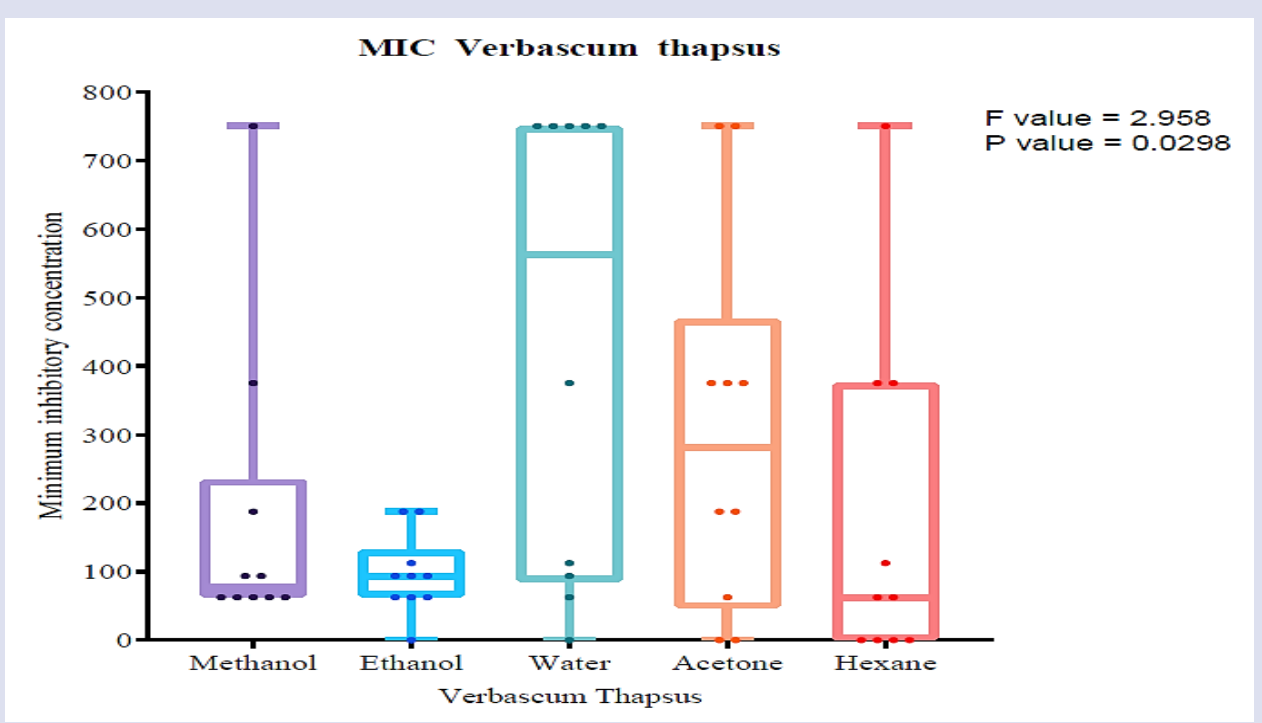

Figure 6: Analysis of Variance (ANOVA) figure for Zone of inhibition (mm) of Verbascum Thapsus plant extracts Against Test Pathogenic Bacterial strains by Kirby's Disc Diffusion method. A significant difference is seen in maximum efficacy of water extract against most bacterial strains and least efficacy in ethanol-based extract.

\section{METHODS}

\section{Plant material}

Verbascum thapsus plants were collected during July 2016 from district swat $\left(35.2227^{\circ} \mathrm{N}, 72.4258^{\circ} \mathrm{E}\right)$, a district in Khyber Pakhtunkhwa (KPK) province Pakistan, and identified by the national herbarium later brought to the laboratory (Antimicrobial Biological Laboratory; AMBL, International Islamic University Islamabad, Pakistan).

\section{Extract preparation and Filtration}

Shade dried Verbascum thapsus plants were chopped and ground to a fine powder. The prepared powder $(200 \mathrm{~g})$ was passed through a sieve (pore size 20-25um) followed by dissolving in five solvents (each solvent $1000 \mathrm{~mL}$ ) of different polarities including Methanol,
Ethanol, Water, Acetone, and Hexane obtained from Stockbridge Medicinal and aromatic Lab, University of Massachusetts Amherst, USA. Plant powder was separately macerated in each of the solvents using a rotary evaporator and shaking at room temperature for two days i.e., 48 hours and then filtered through a Whatmann No. 41 paper.

\section{Phytochemical analysis}

\section{Preliminary qualitative analysis}

The plant extracts prepared in different solvents were subjected to preliminary qualitative analysis by adopting well-established procedures ${ }^{7}$. All the phytochemical tests were performed to confirm the presence of saponin, phenolic compounds, water-soluble phenol, water-insoluble phenol, flavonoids, polysteroids, terpenoids, cardiac 


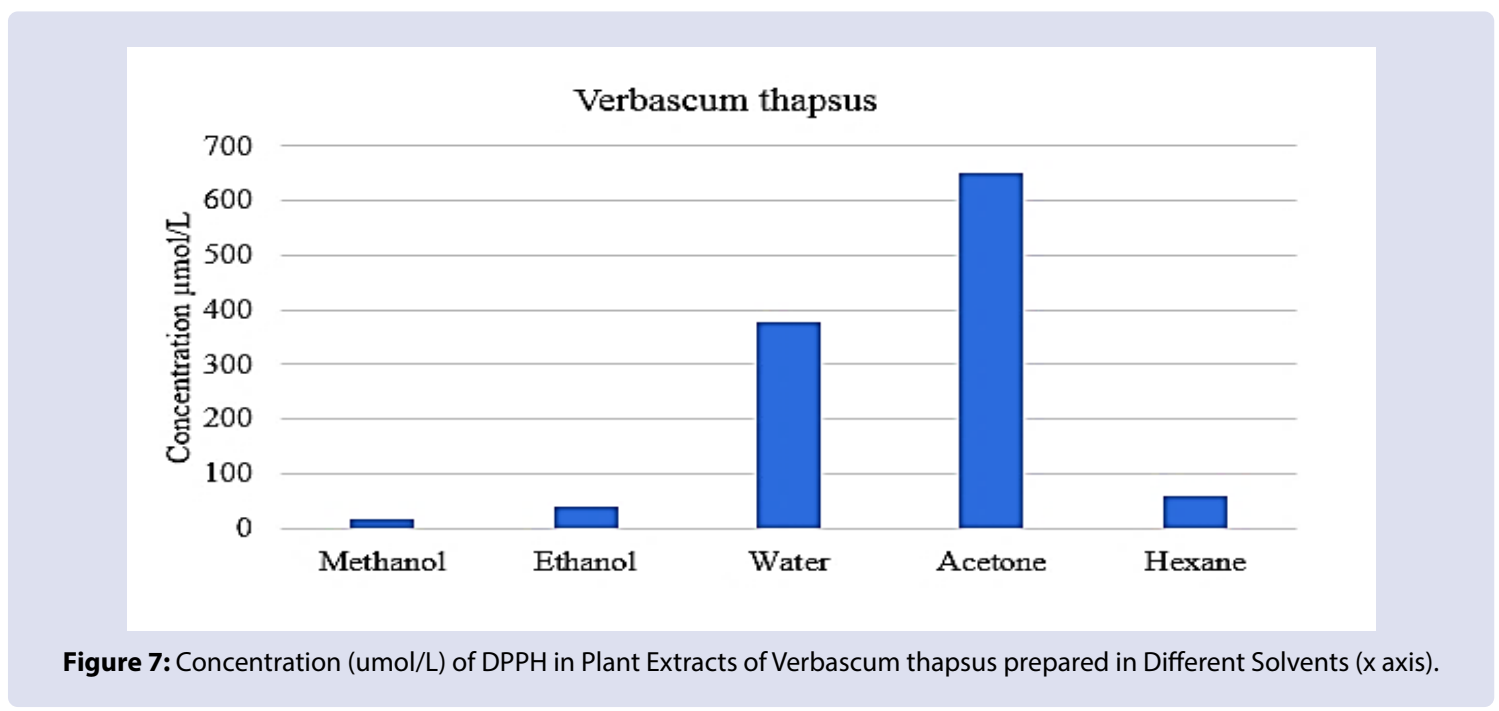

glycosides, free anthraquinones, combined anthraquinones, tannins, and alkaloids in the tested plant samples.

\section{Quantitative analysis}

\section{Phenols}

Phenols were quantified by following the standard procedures ${ }^{7}$. Briefly, $75 \mu \mathrm{L}$ deionized distilled water $(\mathrm{ddH} 2 \mathrm{O})$ was added to each well of 96-well plate. $25 \mu \mathrm{L}$ Folin C (F-C reagent, Sigma-Aldrich) was also added to each well of a plate (diluted $1: 1 \mathrm{v} / \mathrm{v}$ with ddH2O) and left it to stand for $6 \mathrm{~min} .100 \mu \mathrm{L}$ of $\mathrm{Na} 2 \mathrm{CO} 3(75 \mathrm{~g} / \mathrm{L})$ was added to each well. After thorough mixing, plates were put in dark for $90 \mathrm{~min}$. Each of the samples was repeated in triplicate. A spectrophotometric microplate reader (SPECTRA MAX M2e) was used to take readings at $765 \mathrm{~nm}$. Gallic acid was used as a standard at $12.5-400 \mu \mathrm{g} / \mathrm{mL}$ and a standard calibration curve were generated. Phenols were determined as $\mu \mathrm{g}$ of gallic acid equivalents / $\mathrm{mL}$, which was calculated via formula, $\mathrm{y}=$ $0.6053 \mathrm{x}-0.0567$, where $\mathrm{y}$ is the absorbance at $765 \mathrm{~nm}$ and $\mathrm{x}$ is the amount of gallic acid equivalent in $\mu \mathrm{g} / \mathrm{mL}^{30}$.

\section{Flavonoids}

Flavonoids were quantified by following the standard procedures ${ }^{6} .100$ $\mu \mathrm{L} \mathrm{ddH} 2 \mathrm{O}$ was dispensed in each of the 96 wells of the well plate. 10 $\mu \mathrm{L}$ of NaNO2 $(50 \mathrm{~g} / \mathrm{L})$ and $25 \mu \mathrm{L}$ of standard or plant extract sample solution were added to these wells followed by incubation for 5 minutes at room temperature. $15 \mu \mathrm{L}$ of $\mathrm{AlCl} 3(100 \mathrm{~g} / \mathrm{L})$ was added to the mixture and left for 6 minutes. Later, $50 \mu \mathrm{L}$ of $\mathrm{NaOH}(1 \mathrm{~mol} / \mathrm{L})$ and 50 $\mu \mathrm{L}$ of ddH2O were added to each well, and the plate was shaken for 30 $\mathrm{sec}$, and absorbance was measured at $510 \mathrm{~nm}$ using SPECTRA MAX M2e plate reader. Catechin was used as a standard at $5-500 \mu \mathrm{g} / \mathrm{mL}$ to generate calibration curve and flavonoids content of plant extract was expressed in $\mu \mathrm{g}$ of Catechin equivalents / $\mathrm{mL}$ and were calculated by the formula, $y=0.5377 x+0.316$, where $y$ is the absorbance at $510 \mathrm{~nm}$ and $\mathrm{x}$ is the amount of Catechin equivalent in $\mu \mathrm{g} / \mathrm{mL}^{30}$.

\section{DPPH Antioxidant assay}

DPPH radical scavenging assay by ${ }^{31}$ Bersuder, Hole and Smith 1998 was used to determine the antioxidant activity of plant extract. $25 \mathrm{uLof}$ Plant extracts were left to react with free DPPH $(200 \mathrm{uL})$ prepared in ethanol for $6 \mathrm{hrs}$ in dark in all 96 wells. Ascorbic acid was used as a standard at $50-1000 \mu \mathrm{mol} / \mathrm{L}$ concentrations to generate a calibration curve. It was dissolved with DMSO alone to act as a negative control for percentage calculation of plant extract radical scavenging activity. Absorbance was measured at $517 \mathrm{~nm}^{32}$.

\section{Gas Chromatography-Mass Spectrometry (GC/MS) Analysis}

The phytochemical investigation of plant crude extract was performed using GC-MS equipment (Bruker Scion 456 GC, EVOQ triple quadrupole GC-MS/MS) following the standard procedures ${ }^{33}$. The experimental conditions of the GC-MS system were as follows: Column: $15 \mathrm{~m}, 0.25 \mathrm{~mm}$ inner diameter, $0.25 \mathrm{~mm}$ film thickness. The flow rate of the mobile phase (carrier gas: $\mathrm{He}$ ) was set at $1.5 \mathrm{~mL} / \mathrm{min}$. In the gas chromatography part, temperature-programmed (oven temperature) was $45^{\circ} \mathrm{C}$ hold $3 \mathrm{~min}$-raised to $250^{\circ} \mathrm{C}$ at $8^{\circ} \mathrm{C} / \mathrm{min}$ hold $10 \mathrm{~min}$ and injection volume of $1 \mathrm{uL}$ using the varying split ratio (5:1/15:1/20:1). Samples dissolved in all five solvents were run fully at a range of 45$350 \mathrm{~m} / \mathrm{z}$ and the results were compared by using Software MSWS 8, Automated Mass Spectral Deconvolution and Identification System (AMDIS) for GC-MS and NIST library.

\section{Antibacterial activity}

\section{Bacterial cultures collection and Inoculum preparation}

Antibacterial experiments were performed on ten bacterial strains. Gram-positive strains included: Bacillus subtilis (ATCC_6051), Micrococcus luteus (ATCC_4698), Staphylococcus aureus (ATCC_25923), Lactococcus lactis (ATCC_LMO230), Listeria monocytogenes (ATCC_LM21) while the gram-negative bacterial strains included: Shigella sonnei (ATCC_25931), Salmonella enterica (ATCC_14028), Escherichia coli (ATCC_25922) and Klebsiella oxytoca (ATCC_43863).

All these bacteria were separately grown on Tryptic Soy Broth (TSB) medium (Thermo Fisher Scientific, USA) and incubated at $26 \pm 2{ }^{\circ} \mathrm{C}$ for twenty-four hours. All the pure bacterial cultures were stored at -4 ${ }^{\circ} \mathrm{C}$ till further use in experimentation. Bacterial inoculum was prepared by suspending the pure bacterial colonies in $25 \mathrm{~mL}$ capacity lid vials containing sterilized nutrient broth medium followed by incubation at $26 \pm 2{ }^{\circ} \mathrm{C}$ on a rotary shaker for 24 hours. The concentration of each of the bacterial inoculum was maintained at $10^{5}$ to $10^{6} \mathrm{CFU} / \mathrm{mL}$.

\section{Determination of Minimum Inhibitory Concentrations} (MIC) and percentage inhibition / antibacterial activity

The MIC of Verbascum thapsus was investigated by following three methodologies including 96 well test, Kirby-Buyer disk diffusion and resazurin-based well plate microdilution method. 


\section{6 well sterile microtiter tray assay}

96 well sterile microtiter tray assay was reformed by adopting the standard operating procedure ${ }^{12} .100 \mu \mathrm{L}$ TSB medium, $100 \mu \mathrm{L}$ of plant extract fractions at 5 dilution levels $(1000 \mu \mathrm{g}, 500 \mu \mathrm{g}, 250 \mu \mathrm{g}, 125 \mu \mathrm{g}$, and $62.5 \mu \mathrm{g}$ ) and $50 \mu \mathrm{L}$ of each bacterial culture (105 to $106 \mathrm{CFU} /$ $\mathrm{mL}$ concentration) were loaded in the wells ${ }^{34}$. A well-containing TSB medium only (lacks Plant extract and culture) was maintained as a double negative well to check the sterility of the medium. Another wellcontained TSB medium and bacterial inoculation (lacks Plant extract) to check average bacterial growth trends as single negative control wells. Plates were covered, sealed, and incubated at room temperature for 24 hours. Standard readings for MIC were taken by recording the absorbance at $570 \mathrm{~nm}$ on Elx 800 plate reader. The following formula was used for the calculation of bacterial inhibition: Percentage Inhibition $=\left[\frac{O D \text { in control }-O D \text { in treatment }}{O D \text { in control }}\right] \times 100$

\section{Kirby-Bauer Disk Diffusion Method}

The Paper disc diffusion method proposed by Kirby ${ }^{13}$ was used to evaluate the antimicrobial potency of all plant extracts. In this assay, solidified agar plates were swabbed with 24 hours old bacterial inoculum $(106 \mathrm{CFU} / \mathrm{mL})$ under aseptic conditions. Paper discs $(10 \mathrm{~mm})$ were soaked in $20 \mathrm{ul}$ of prepared plant extract at all concentrations (i.e., $1000 \mu \mathrm{g}, 500 \mu \mathrm{g}, 250 \mu \mathrm{g}, 125 \mu \mathrm{g}$, and $62.5 \mu \mathrm{g}$ ) and were placed on to the solidified culture media under aseptic conditions followed by incubation at $26 \pm 2{ }^{\circ} \mathrm{C}$ for 24 hours. The negative control contained paper discs dipped in distilled water. All the experimental treatments were repeated five times. The zone of inhibition $(\mathrm{mm})$ was measured to confirm the susceptibility of bacterial agents ${ }^{35}$.

\section{Resazurin based Well Plate Microdilution Method}

The resazurin-based Well Plate Microdilution test was performed by adopting the standard procedure ${ }^{14}$. Before the test, Resazurin (7-Hydroxy-3H-phe-noxazin-3-one 10-oxide) solution was prepared by adding $121.5 \mathrm{mg}$ of resazurin powder in $18 \mathrm{~mL} \mathrm{ddH} 2 \mathrm{O}$ and was homogenized on a vortex mixer for 1 hour. Phosphate Buffer Saline (PBS) was used to adjust the $\mathrm{pH} 7.4$ of the solution. The total plant extract was prepared by mixing all the five extracts in Dimethyl sulfoxide (DMSO) to yield a homogenous mixture. $100 \mu \mathrm{L}$ of TSB liquid medium and total plant extract was added to the wells ${ }^{36} 24$ hours old bacterial inoculum $(106 \mathrm{CFU} / \mathrm{mL})$ of each bacterium were added to these wells. To ensure media sterility Double negative control wells were maintained that contain TSB medium only. Single negative control wells contained TSB, bacterial culture, and Resazurin. After overnight incubation at $26 \pm 2{ }^{\circ} \mathrm{C}, 20 \mu \mathrm{L}$ of Resazurin dye was added to each well and again incubated for $2-4 \mathrm{~h}$ for the development of color change. Absorption readings of resazurin developed color intensity were taken at $550-590 \mathrm{~nm}$ wavelength by using the SPECTRA MAX M2e plate reader ${ }^{36}$.

\section{Statistical analysis}

Results or antimicrobial activity were statistically analysed using GraphPad prism version 8.0 and Microsoft office excel 2010 version. Means, Standard Deviations, and a One-way analysis of variance (ANOVA) test was performed for statistically testing the zone of inhibition of bacterial strains presented by Kirby's disc diffusion method to evaluate the antibacterial activity of plant extracts. The significance threshold was kept at 0.05 probability.

\section{CONCLUSION}

Important phytochemicals including phenols, flavonoids, alkaloids, tannins, and glycosides were indicated in Verbascum thapsus extracts via phytochemical analyses, antimicrobial activity, antioxidant assays, and GCMS analyses. The antioxidant and antimicrobial activity were observed against most bacterial strains and has the potential for development as a bactericide and medicinally important drug.

\section{ACKNOWLEDGMENTS}

Funding: The authors acknowledge Higher Education Commission, Government of Pakistan for funding, facilities and opportunities created under International Research Support Initiative Program and University of Massachusetts, USA for providing facilities of GCMS.

Author Contributions: All authors contributed towards study designing and implementation. Practical performance and Data compilation was performed solely by A. N. Experimental Assistance for GC-MS and Antibacterial analysis was given by L. E. C. and T. M. Manuscript Drafting and Proofreading was assisted by Dr. B. A., A. N. and H. S.

\section{ADDITIONAL INFORMATION}

Conflicts of interest/Competing interests: Authors declare no conflict of interests.

Availability of data and material: GCMS Data has been given in supplementary files further materials or relevant data will be available upon request to author.

Code availability: Not Applicable.

\section{REFERENCES}

1. Thomson W.A., Schultes R.E. Medicines from the Earth. McGrawHill, 1978.

2. Mahdavi S., Amiradalat M., Babashpour M., Sheikhlooei H., and Miransari M. The antioxidant, anticarcinogenic and antimicrobial properties of Verbascum thapsus L. Medicinal Chemistry. 2020;16(7):991-995

3. M Amin H. I., Hussain F. H., Gilardoni G., Thu Z. M., Clericuzio M. \& Vidari G. Phytochemistry of Verbascum Species Growing in Iraqi Kurdistan, and Bioactive Iridoids from the Flowers of Verbascum calvum. Plants. MDPI. 2020;9(9):1066.

4. Prakash V., Rana S., Sagar A. Studies on antibacterial activity of Verbascum thapsus. J. Med. Plants Stud. 2016;4(3):101-103.

5. Ali N., Shah S.W., Shah I., Ahmed G., Ghias M., Khan I., Ali W Anthelmintic and relaxant activities of Verbascum Thapsus Mullein. BMC Compl Alternative Med. 2012;12(1):1-7.

6. Dar M. A., Bhat M. F., Hassan R., Masoodi M. H., Mir S. R., \& Mohiuddin R. Extensive phytochemistry, comprehensive traditional uses, and critical pharmacological profile of the great mullein: Verbascum thapsus $L$. The Natural Products Journal. 2019; 9(3): 158-171.

7. Winnett V., Boyer H., Sirdaarta J., Cock I.E. The potential of Tasmannia lanceolata as a natural preservative and medicinal agent: Antimicrobial activity and toxicity. Pharmacog Commun. 2014; 4(1):42-52.

8. Georgiev M.I., Ali K., Alipieva K., Verpoorte R., Choi Y.H. Metabolic differentiations, and classification of Verbascum species by NMRbased metabolomics. Phytochemistry. 2011;72(16): 2045-2051.

9. Dulger G., Tutenocakli T., Dulger B. Antimicrobial potential of the leaves of common mullein (Verbascum thapsus L., Scrophulariaceae) on microorganisms isolated from urinary tract infections. J. Med. Plants Stud. 2012; 3(2):86-89.

10. Tatli I.I., Akdemir Z.F. Traditional uses and biological activities of Verbascum species. Fabad J. Pharm. Sci. 2006; $31(2): 85$.

11. Soltaninejad M., Akhgar M.R. Chemical composition of the essential oil of Verbascum songaricum from Iran. J. Bio. \& Env. Sci. 2015; 26:345-349 
12. Taleb S., and Saeedi, M. The effect of the Verbascum Thapsus on episiotomy wound healing in nulliparous women: a randomized controlled trial. BMC Complementary Medicine and Therapies. 2021; 21(1):1-9.

13. Tungmunnithum D., Thongboonyou A., Pholboon A., Yangsabai A. Flavonoids and other phenolic compounds from medicinal plants for pharmaceutical and medical aspects: An overview. Medicines. 2018; 5(3):93.

14. Klimek B., Olszewska M.A., Tokar M. Simultaneous determination of flavonoids and phenylethanoids in the flowers of Verbascum densiflorum and $\mathrm{V}$. phlomoides by high-performance liquid chromatography. Phytochemical Analysis. Int. J. Plant Chem. Biochem. Tech. 2010; 21(2):150-156.

15. Grigore A., Colceru-Mihul S., Litescu S., Panteli M., Rasit I. Correlation between polyphenol content and anti-inflammatory activity of Verbascum phlomoides (mullein). Pharm. Biol. 2013;51(7):925-929.

16. Saltan F.Z., Sokmen M., Akin M., Saracoglu H.T., Gokturk R.S. Ahmad M., Ali M., Shah M.R. Antimicrobial, and antioxidant activities of phenolic compound extracted from new Verbascum species growing in Turkey. J. Chem. Soc. Pak. 2011;33(5):764-771.

17. Wink M., Botschen F., Gosmann C., Schäfer H., Waterman P.G. Chemotaxonomy seen from a phylogenetic perspective and evolution of secondary metabolism. Annu. Rev. Plant Biol. 2018: 364-433.

18. Tariq A., Shah G.M., Ahmad Zada A.A., Shah A.Z., Fatima I. Phytochemical analysis and in-vitro anti-bacterial and anti-fungal activity of Verbascum arianthum (Benth). Pure and Applied Biology. 2020; 10(3): pp797-806.

19. Ozcan B., Yilmaz M., Caliskan M. Antimicrobial, and antioxidant activities of various extracts of Verbascum antiochium Boiss. (Scrophulariaceae). J. Med. Food. 2010; 13(5):1147-1152.

20. Tiwari J.K., Ballabha R., Tiwari P. Diversity, and present status of medicinal plants in and around Srinagar hydroelectric power project in Garhwal Himalaya, India needs for conservation. Researcher. 2010; 2(2):50-60.

21. Parekh J., Jadeja D., Chanda S. Efficacy of aqueous and methanol extracts of some medicinal plants for potential antibacterial activity. Turk. J. Biol. 2006;29(4):203-210.

22. Dulger G., Tutenocakli T., Dulger B. Anti-staphylococcal activity of Verbascum thapsus L. against methicillin-resistant Staphylococcus aureus. Konuralp Tip Dergisi. 2017; 9(1):53-57.

23. Shakeri A.R., Farokh A. Phytochemical evaluation and antioxidant activity of Verbascum sublobatum Murb. leaves. RJP. 2015;2(3):43-47.

24. Weldegebrieal, G.K. Photocatalytic and antibacterial activity of $\mathrm{CuO}$ nanoparticles biosynthesized using Verbascum thapsus leaves extract. Optik. 2020;204: p.164230.
25. Yabalak, E., Ibrahim F., Eliuz E.A.E., Everest A., Gizir, A.M. Evaluation of chemical composition, trace element content, antioxidant, and antimicrobial activities of Verbascum pseudoholotrichum. Plant Biosystems. 2020:1-10.

26. Prakash V., Sagar A. To investigate leaf extracts of Verbascum thapsus Linn. For their antioxidant potential. J. Med. Plants. 2021;9(1): pp.37-40.

27. Alan S., Saltan F.Z., Gktrk R.S., Skmen M. Taxonomical properties of three Verbascum L. species and their antioxidant activities. Asian J. Chem. 2009;21(7):5438.

28. Selseleh M., Ebrahimi S.N., Aliahmadi A., Sonboli, A., and Mirjalili M.H. Metabolic profiling, antioxidant, and antibacterial activity of some Iranian Verbascum L. species. Ind. Crops and Prod. 2020;153: p.112609.

29. Aydin Ç., Rakhimzhanova A., Kilinçarslan Ö., and Mammadov R. Antioxidant and phenolic characterization with HPLC of various extract of Verbascum glomeratum Linneus. J. Chem Soc Pak. 2020;42(2): p.222

30. Herald T.J., Gadgil P., Tilley M. High-throughput micro plate assays for screening flavonoid content and DPPH-scavenging activity in sorghum bran and flour. J. Sci. Food Agric. 2012;92(11):2326-2331.

31. Bersuder P., Hole M., Smith G. Antioxidants from a heated histidine-glucose model system. Investigation of the antioxidant role of histidine and isolation of antioxidants by high-performance liquid chromatography. J. Am. Oil Chem. Soc. 1998; 75(2):181-187.

32. Shimada K., Fujikawa K., Yahara K., Nakamura T. Antioxidative properties of xanthan on the autoxidation of soybean oil in cyclodextrin emulsion. J. Agric. Food Chem. 1992;40(6):945-948.

33. Fan H., Sun L., Yang L., Zhou J., Yin P., Li K., Xue Q., Li X., Liu $Y$. Assessment of the bioactive phenolic composition of Acer truncatum seed coat as a by-product of seed oil. Ind. Crops Prod. $2018 ; 118: 11-19$

34. Andrews J.M. Determination of minimum inhibitory concentrations. J. Antimicrob. Chemother. 2001; 48:5-16.

35. Dunkelberg $\mathrm{H} .:$ Carcinogenic activity of ethylene oxide and its reaction products 2-chloroethanol, 2-bromoethanol, ethylene glycol and diethylene glycol. Carcinogenicity of ethylene oxide in comparison with 1,2-propylene oxide after subcutaneous administration in mice (author's transl). Zentralblatt fur Bakteriologie, Microbiology und Hygiene. 1. Abt. Original B, Hygiene. 1981;174(5): 383-404.

36. Elshikh M., Ahmed S., Funston S., Dunlop P., McGaw M., Marchant R., Banat I.M. Resazurin-based 96-well plate microdilution method for the determination of minimum inhibitory concentration of biosurfactants. Biotechnol. Lett. 2016; 38(6):1015-1019. 


\section{GRAPHICAL ABSTRACT}

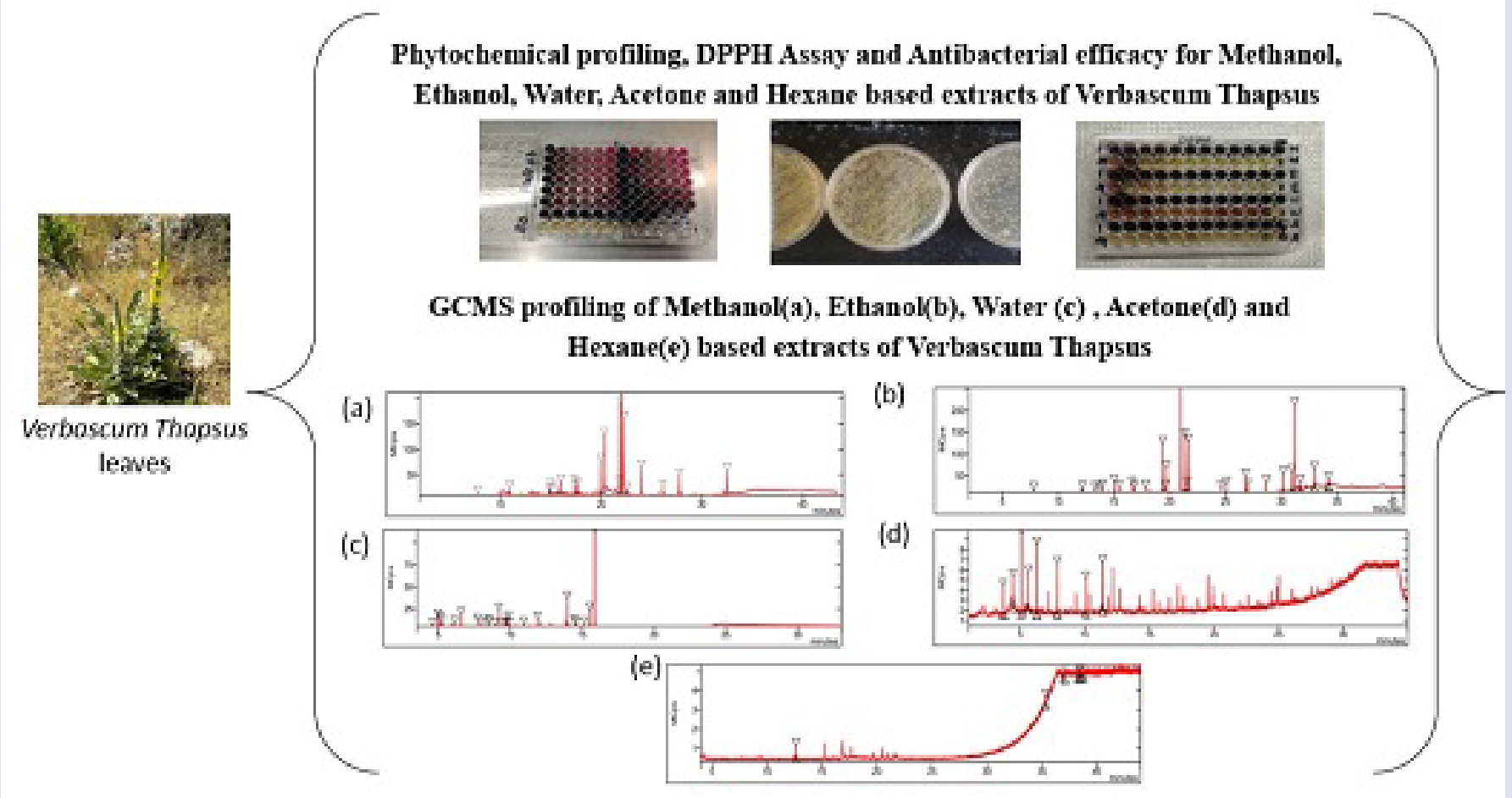

\section{ABOUT AUTHORS}

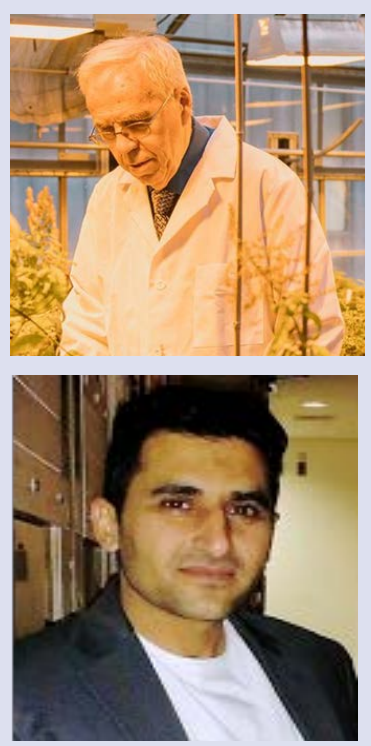

Lyle E. Craker is a Professor in the Department of Plant, Soil and Insect Sciences at the University of Massachusetts Amherst. Since 2001, Craker has been trying to obtain a permit from the United States Drug Enforcement Administration (DEA) to grow marijuana for research purposes. In 1963, Craker received a B.S. degree in agronomy from the University of Wisconsin, Madison. In 1967 he received a Ph.D. in agronomy and plant genetics with a specialty in plant physiology from the University of Minnesota. In 1976 he received an associate degree in business administration from Massachusetts Bay Community College.

Dr. Bashir Ahmed is assistant professor in faculty of basic and applied sciences. He is PhD in Microbiology, from university of Quaid e Azam, Islamabad, Pakistan and A Post doctorate from University of Cambridge, UK. His main field of expertise are applied microbiology, biotechnology, Characterization pf Plants molecules, formulation of microbial enzymes and commercial applications, extremophiles and extremophytes.

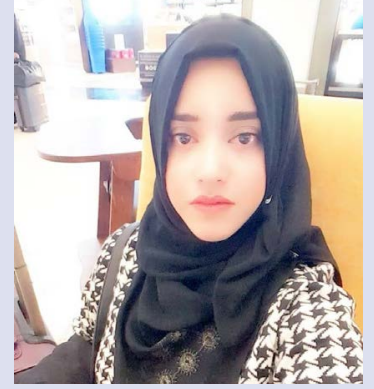

Hira Shahzad is a Ph.D. Scholar of Biochemistry at University Institute of Biochemistry and Biotechnology (UIBB), PMAS Arid Agriculture University Rawalpindi Shamsabad, Murree Road Rawalpindi. She completed her MPhil from University Institute of Biochemistry and Biotechnology (UIBB), PMAS Arid Agriculture University, Rawalpindi. Ms. Shahzad has experience in molecular biology and techniques, as her MS desertion was based on cancer genetics. Ms. Shahzad's doctorate interest is against infectious microbes specially Mycobacterium tuberculosis and epigenetic aspects, including assays like ELISA etc. 


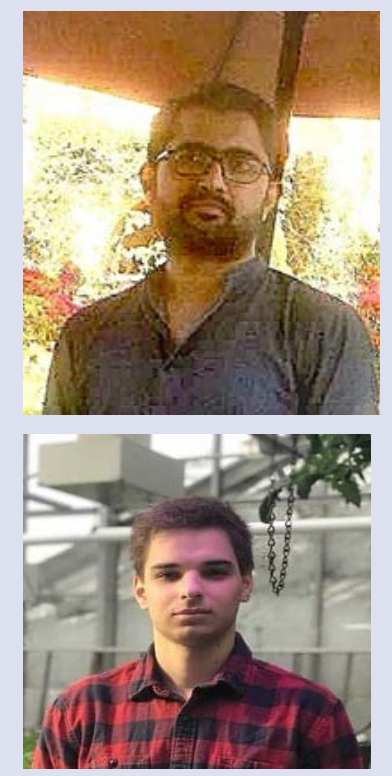

Ali Nadeem is Ph. D Scholar in Islamic International University, Islamabad and completed his research work in University of Massachusetts. Amherst USA. He completed his MS from Quaid e Azam University, Islamabad, and master's from PMAS, University of Arid Agriculture, Rawalpindi. Nadeem has experience in molecular biology and techniques, as his MS desertion was based on cardiovascular disease and molecular inclusions. Nadeem's doctorate interest has been extremophytes, metabolomics, characterization of medicinal plants, molecules, and chemistry against infectious microbes.

Tudor Muntean is an analytical chemist based in Andover, MA. His research interest includes natural product extraction, chromatography, and mass spectrometry. He received a B.S. in chemistry from University of Massachusetts at Amherst in 2019. He conducted research in medicinal plants at Stockbridge school of Agriculture, University of Massachusetts, MA, USA.

Cite this article: Nadeem A, Ahmed B, Shahzad H, Craker LE, Muntean T. Verbascum Thapsus (Mullein) Versatile Polarity Extracts: GC-MS Analysis, Phytochemical Profiling, Anti-bacterial Potential and Anti-oxidant Activity. Pharmacogn J. 2021;13(6): 1488-1497. 